\title{
The Great Depression in Italy: Trade Restrictions and Real Wage Rigidities
}

\author{
Fabrizio Perri and Vincenzo Quadrini
}

The economic recession experienced by many countries in the late 1920s and early 1930s - the Great Depression - also affected Italy. Despite the lower degree of industrial development in the Italian economy, the dynamics of the Depression in Italy were not very different from those of more industrialized countries like England, France, and the United States. Although the fall in aggregate production was smaller, the contraction in industrial production was as severe as in more industrialized countries. More broadly, the key features of the Italian Depression can be summarized as follows:

1. Large and persistent decline in international trade

2. Large fall in hours worked and production in the tradable sector, but negligible changes in the nontradable sector

3. Large fall in investment

4. Stability of real wages

A striking aspect of the Great Depression is that it involved many countries during the same time period. This consideration leads us to investigate possible mechanisms of international transmission. Among these mechanisms, the fall in international trade constitutes the obvious candidate. In fact, all countries affected by the Great Depression also experienced a drastic and persistent fall in foreign trade.

Finding the causes of the fall in foreign trade is not difficult. Many countries, including Italy, implemented protectionist policies starting in the late 1920s. These policies took several forms, such as import tariffs, currency control, and quota restrictions. The consequence was a dramatic fall in international trade. Can this fall in international trade explain the Great Depression in Italy? In this paper we argue that the drop in international trade was indeed 
a major cause of the economic downturn in Italy in the 1930s, and that the slump was amplified by the rigidity of real wages.

We develop an open economy model with two sectors of production: the tradable sector and the nontradable sector. The tradable and nontradable productions are then combined to produce consumption and investment in the two sectors. A key property of the model is that foreign imports are an important input in the production of investment in the tradable sector. This assumption is based on the import structure of Italy in the 1920s and 1930s, where a significant share of nonfarm imports were investment goods for the industrial sector. This dependence on the import of investment goods - which derives from the lower development of the industrial sector in Italy — was an important mechanism of transmission of the international economic crisis in Italy. Using a calibrated version of the model, we show that the contraction in the foreign trade can account for features 2 and 3 of the Italian Depression just listed. The role played by the stability of real wages (4) has been to amplify the consequences of the trade contraction. Our work is related to and has been inspired by the papers of Cole and Ohanian (1999 and 2001), who analyzed the Great Depression in the United States. Few authors have analyzed the Great Depression in Italy, but none (to our knowledge) has done it using an explicit macroeconomic model. ${ }^{1}$

\section{The Italian Economy in the Interwar Years}

In this section we present some basic facts about the Italian economy in the interwar years. We first compare the performance of the Italian economy to the performance of other countries in terms of per capita gross domestic product (GDP), industrial production, and international trade. We then document the pattern of other aggregate and sectoral disaggregated data more specifically for Italy.

\section{Italy in the International Context}

Figures 1 and 2 plot the detrended patterns of per capita GDP and per capita industrial production during the Depression, ${ }^{2}$ while Table 1 presents simple measures of depth (peak-to-trough percentage drop) and persistence (years needed to reach back to the 1929 level). The data clearly show that Italy experienced a major and persistent slowdown in GDP growth, although less severe than some other countries, and a significant and persistent drop in industrial production. ${ }^{3}$ These two figures and Table 1 also show that (a) the Great Depression involved many countries in a synchronous way, and (b) the size and persistence of the drop in industrial production were bigger than for GDP. 
Figure 1. Real GDP per capita

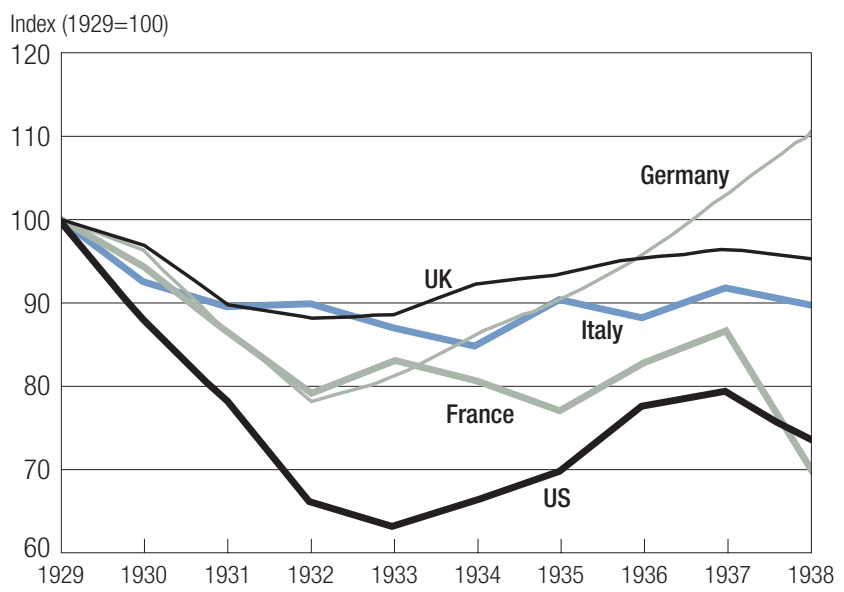

Figure 2. Industrial production per capita

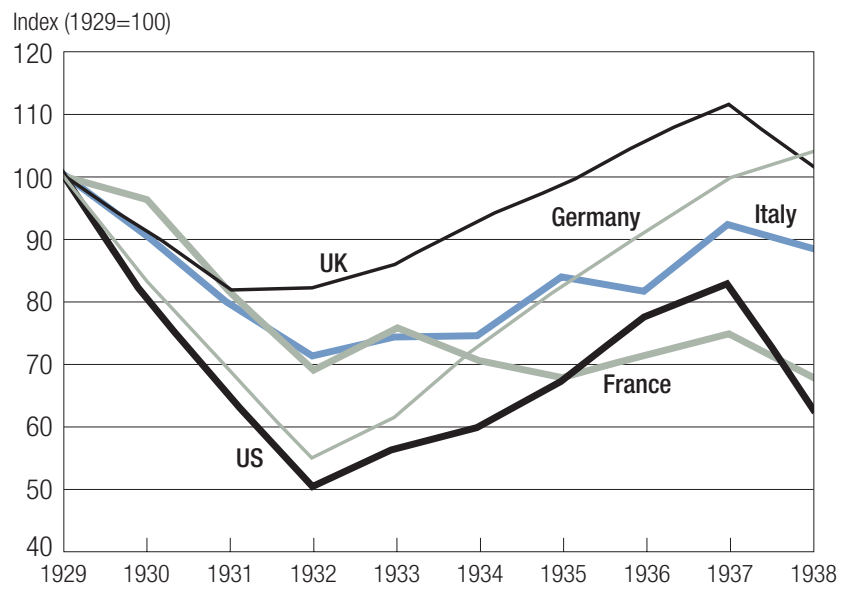

The fact that the Great Depression was so synchronous across countries suggests that common factors may be important explanations for the Depression. One possible candidate is the contraction of trade in the interwar years. Table 2 shows that trade (measured as imports and exports) fell during the Depression years more severely than GDP in all countries, suggesting the presence of increasing obstacles to trade during this period. A more direct indication of trade restrictions is the tariff increases in the late 1920s and 
Table 1. Decline from peak to trough, years to return to 1929 level

\begin{tabular}{lcrlrr}
\hline & \multicolumn{2}{c}{ GDP } & & & \multicolumn{2}{c}{$\begin{array}{c}\text { Industrial } \\
\text { production (IP) }\end{array}$} \\
\cline { 2 - 3 } \cline { 5 - 6 } & Decline (\%) & Years & & Decline (\%) & Years \\
\hline United States & 31.8 & $>10$ & & 46.5 & $>10$ \\
France & 15.9 & 8 & & 26.7 & $>10$ \\
Germany & 17.8 & 6 & & 41.9 & 7 \\
Italy & 7.0 & 6 & & 24.5 & 8 \\
United Kingdom & 6.7 & 5 & & 14.7 & 5 \\
\hline
\end{tabular}

Source: Data for GDP from Maddison 1991; data for IP from OEEC 1958, Industrial Statistics.

Table 2. Fall in real GDP, real exports, real imports, 1929-32

\begin{tabular}{lccc}
\hline & $\begin{array}{c}\text { GDP } \\
\text { decline (\%) }\end{array}$ & $\begin{array}{c}\text { Imports } \\
\text { decline (\%) }\end{array}$ & $\begin{array}{c}\text { Exports } \\
\text { decline (\%) }\end{array}$ \\
\hline United States & 28.2 & 39 & 48 \\
France & 14.6 & 11 & 41 \\
Germany & 15.8 & 29 & 41 \\
Italy & 2.5 & 28 & 19 \\
United Kingdom & 5.8 & 12 & 37 \\
\hline
\end{tabular}

Source: Data for GDP from Maddison 1991; data for trade from Maddison 1962.

early 1930s. Crucini and Kahn (1996) report that average ad valorem tariffs in a sample of industrialized countries rose from 9.9 percent in 1920-29 to 19.9 percent in 1930-40. For Italy the increase in the same period was from 4.5 percent to 16.8 percent. Increased tariffs, however, were only part of the increasingly protectionist policies. For Italy, a set of rules and regulations was introduced in the late 1920s and early 1930s that explicitly attempted to reduce imports. ${ }^{4}$ Examples of these rules include the requirement that Italian products had to have a minimum level of Italian intermediate inputs; the prohibition of the import of goods through the postal service; the strict application of preference rules for domestic products in government and military purchases; and foreign exchange controls. For a more extensive list of import restrictions, see the work of Guarneri (1988, Chap. 7). The introduction of these protectionist policies leads us to investigate the extent to which these policies can account for the economic downturn of the Italian economy during the first half of the 1930s. ${ }^{5}$ 


\section{Figure 3. Sectoral decomposition of real GDP}

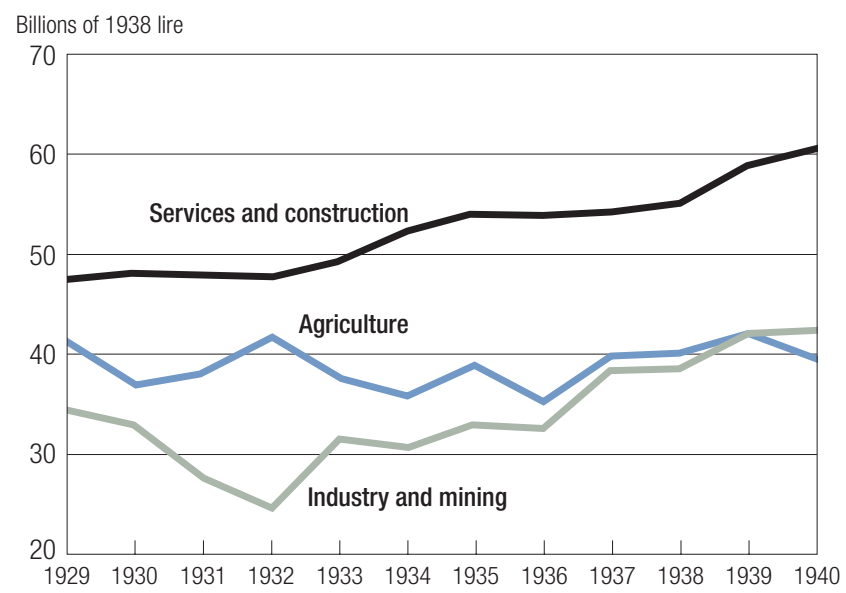

\section{Performance of the Nonfarm Sector}

One reason why the drop in GDP during the Depression was smaller in Italy than in other countries is because Italy was characterized by a larger agricultural sector. Figure 3 reports the sectoral decomposition of GDP in Italy and shows that agricultural production was large (about 40 percent of GDP) but relatively unaffected by the Depression. Although there was a drop in agricultural output from 1929 to 1930, the size of the decline was not different from previous and successive declines. Also, in 1930 and 1931, agricultural production experienced positive growth, unlike the other two sectors.

Because agricultural production was not affected in important ways by the Great Depression, in the remainder of the paper we will concentrate our analysis on the nonfarm sector. Figure 4 plots a measure of detrended total factor productivity in the nonfarm sector. Note that the size and persistence of the observed productivity drop during the Depression were not significantly bigger than those observed in other interwar contractions (not shown in the figure). In line with the findings of Cole and Ohanian (1999) for the United States, Figure 4 suggests that although technology shocks may have played a role in the first part of the recession, these shocks cannot account for the persistence of the Great Depression. In fact, the level of productivity is very low only in 1931 and 1932, whereas per capita GDP is still below trend at the end of the 1930s despite the subsequent productivity improvements.

Therefore, other factors must have played a role. As we already mentioned, the contraction of trade might be one of these factors. Figure 5 plots 


\section{Figure 4. Nonfarm TFP}

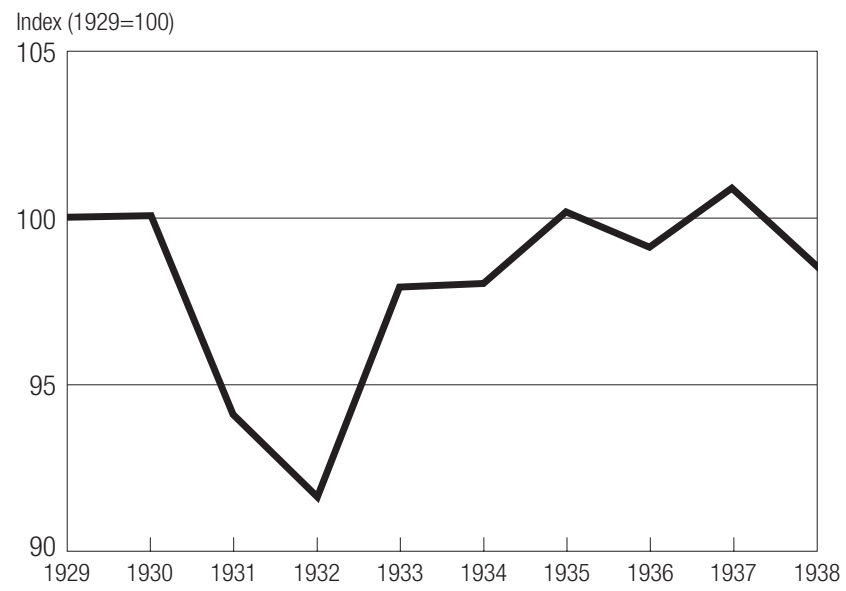

Figure 5. Nonfarm imports, exports

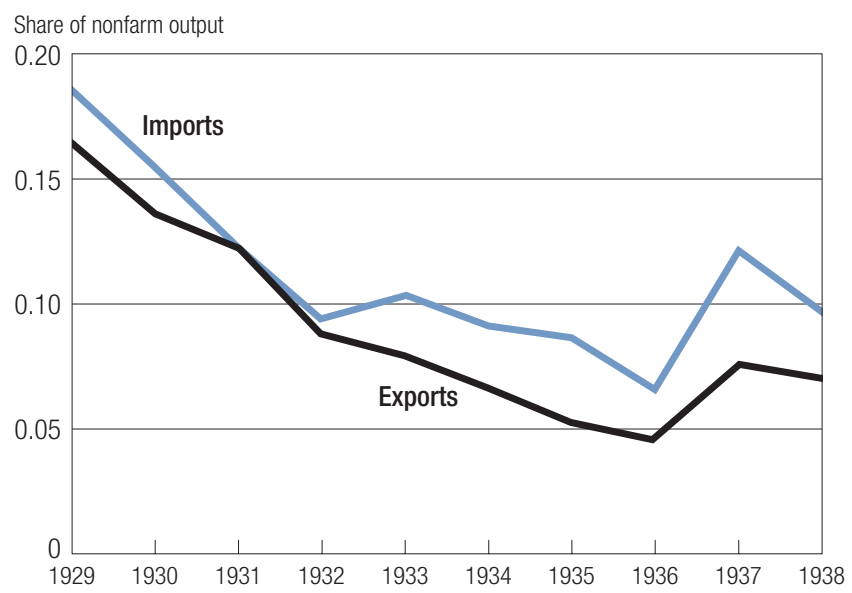

the ratio of nonfarm exports and imports to GDP in Italy from 1929 to 1938 , and shows that these ratios experienced a large and rapid decline during the period of the Depression and remained low in successive years. In contrast, throughout the 1920s, these ratios were roughly constant (around 21 percent). Accordingly, we will focus our analysis on the effects of trade restrictions and ask whether they can account for the Italian Depression.

Finally, Figure 6 shows the patterns of per capita nonfarm real consump- 
Figure 6. Consumption, hours, investment, output per capita

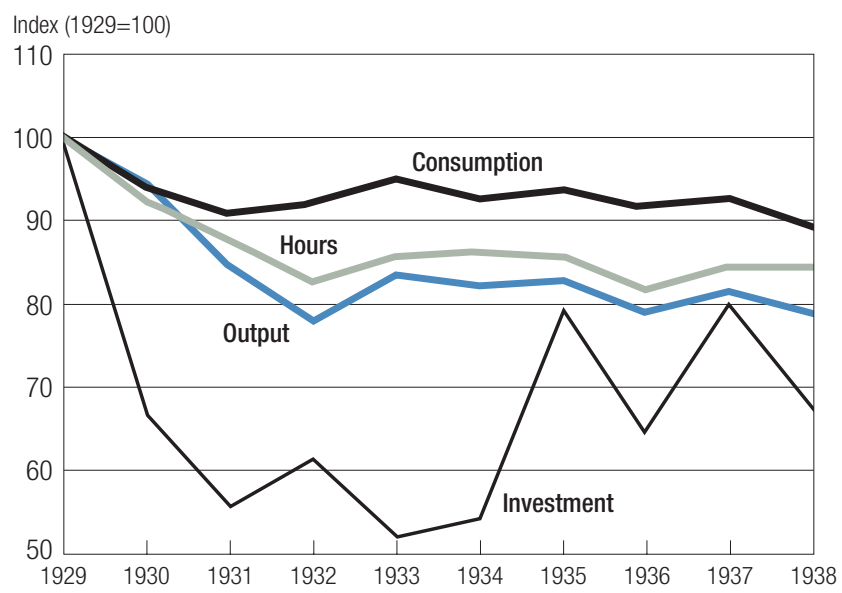

tion, per capita nonfarm real investment, output, and total hours worked in the Depression. Each series is detrended linearly. To estimate the trend, we follow Cole and Ohanian (1999), who use data in the pre-Depression and postwar periods. In particular, we use data for the 1920-29 and 1951-90 periods. Notice that while consumption is marginally affected by the Great Depression, the fall in investment is very severe and prolonged. Hours and output also fall by more than 10 percent and are still below the long-run trend in 1938.

\section{Relative Prices, Wages, and Other Sectoral Evidence}

In the model presented in the next section, we show that trade restrictions can have a substantial impact on production by increasing the cost of foreign inputs used in production and by reducing demand for domestic tradables. Another important effect of trade restrictions is that they reduce the demand for domestic tradables (given the reduction in exports), with a consequent fall in their relative prices. This, in turn, may result in a shift of resources from the tradable sector to the nontradable sector. In this section we document patterns for prices, wages, and production in the two sectors observed in Italy during the contraction period.

Figure 7 shows that the price of nonfarm tradable goods (manufacturing plus mining with or without agricultural goods) fell rapidly relative to the price of nontradable goods (construction and services). Our theoretical hypothesis is that trade restrictions were causing both the decline in exports and imports (displayed in Figure 5) and the increase in the relative price of 
Figure 7. Relative price of nontradables

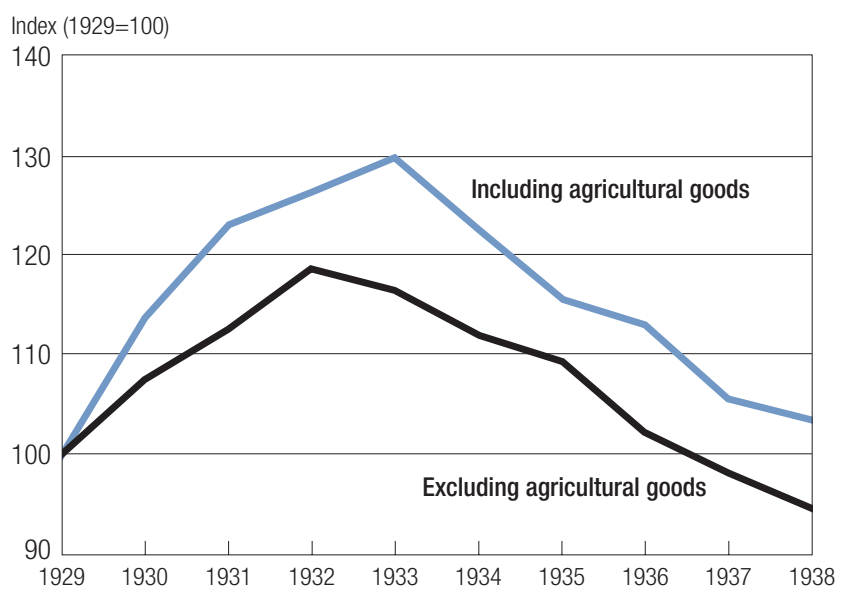

nontradables (displayed in Figure 7).

Figure 8 shows real wages and the pattern of hours worked in the two production sectors. In this figure we use real wages as a measure of the relative labor costs. For this reason, they are deflated by the price index of the sector in which they are paid. Note that almost all the difference in the pattern of real wages can be attributed to the pattern of relative prices. In fact, there is very little difference between the series for nominal wages in the two sectors. Notice also that during the contraction, a sharp and persistent increase in real wages in the tradable sector was associated with a large and persistent decline in total hours. The strong negative correlation between real wages and total hours seems to indicate that the reduction in hours worked was caused by movements along the aggregate labor demand, rather than by shocks in the labor demand itself, thus suggesting the presence of some form of real wage rigidity.

Some economists (see, for example, Bernanke and Carey 1996) have argued that nominal wage rigidities might have caused reductions in labor demand and thus might have been responsible for the slowdown. In Italy, nominal rigidities do not seem very relevant due to the particular political situation. The fascist regime was able to set the nominal wage through the corporate system, and there was surprisingly little worker resistance to nominal wage cuts. ${ }^{6}$ After the 1929 crisis hit, it appears that the deliberate nominal wage policy (see Zamagni 1976) was to keep the real daily wage (that is, the daily nominal wage deflated by the consumer price index-CPI) 
at the 1929 level. Together with this policy, a progressive reduction of the workday was implemented in labor contracts. These two policies together meant that although the real (CPI-deflated) daily wage was kept constant, the real (CPI-deflated) hourly wage increased. Figure 9 documents the patterns for nominal hourly wages and hourly and daily real wages, and shows that even though the daily wage was fairly constant, the real hourly wage increased by about 20 percent. This pattern, together with the behavior of the relative price of tradables, caused, as seen in Figure 8, an increase in the labor costs in the tradable sector of more than 20 percent.

Figure 8. Real wages, total hours (deflated with sector prices)
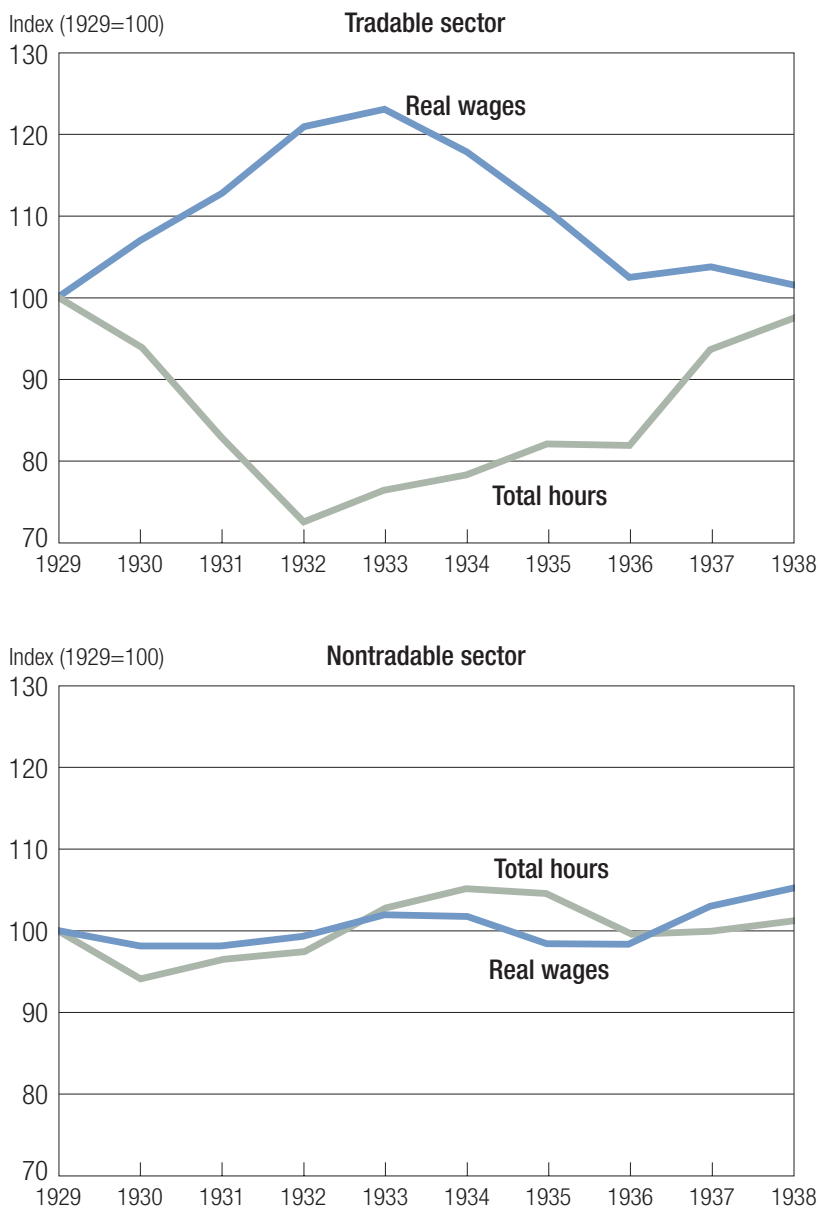
Figure 9. Nominal and real wages (deflated with CPI)

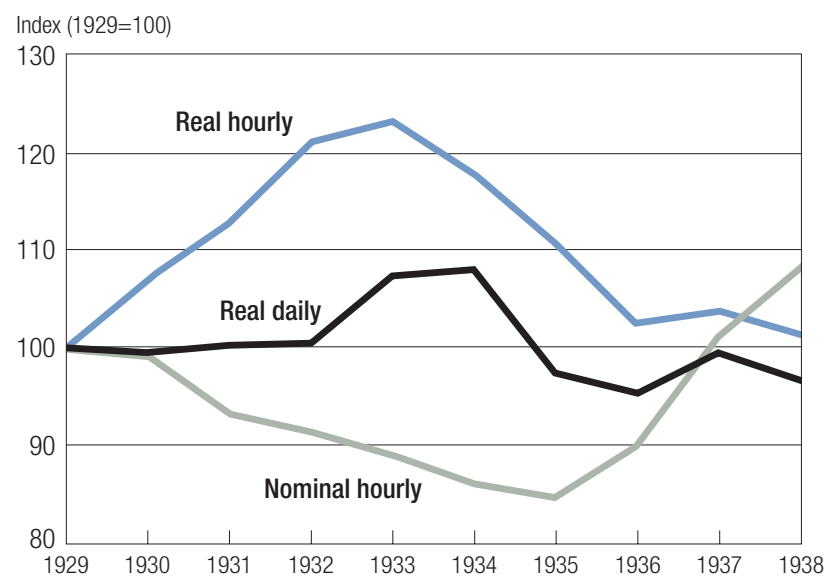

\section{The Model}

In this section we present a model of the Italian economy during the interwar years. The economy is a two-sector open economy model populated by a continuum of households that maximize the lifetime utility:

(1) $\sum_{t=0}^{\infty} \beta^{t} U\left(C_{t}, 1-H_{t}\right)$

where $U(\cdot, \cdot)$ is a standard utility function, $\beta$ is the intertemporal discount rate, $H_{t}$ is working hours, and $C_{t}$ is a composite consumption good resulting from the aggregation of three consumption inputs: consumption goods produced in the nontradable sector $(N), C_{N, t}$; consumption goods produced in the tradable sector $(T), C_{T, t}$; and consumption goods imported $(M)$ from abroad, $C_{M, t}$. The aggregation function for these three inputs is

$$
\begin{aligned}
C & =\Phi\left(C_{N}, C_{T}, C_{M}\right) \\
& =\left[a_{C} \cdot C_{N}^{\frac{\sigma-1}{\sigma}}+\left(1-a_{C}\right) \cdot\left(b_{C} \cdot C_{T}^{\frac{\varepsilon-1}{\varepsilon}}+\left(1-b_{C}\right) \cdot C_{M}^{\frac{\varepsilon-1}{\varepsilon}}\right)^{\frac{\varepsilon(\sigma-1)}{(\varepsilon-1) \sigma}}\right]^{\frac{\sigma}{\sigma-1}} .
\end{aligned}
$$

The parameter $\sigma$ is the elasticity of substitution between the consumption input produced in the nontradable sector and a composite input of tradable goods produced domestically and abroad. The elasticity of substitution between the domestic tradable input and the foreign input is $\varepsilon$. The parameters 
$a_{C}$ and $b_{C}$ will determine the shares of the three inputs.

The production of nontradable and tradable goods takes place according to the following constant-returns-to-scale technologies:

$$
Y_{i}=A_{i} K_{i}^{\theta} H_{i}^{1-\theta}, \quad i=N, T,
$$

where $Y_{i}, A_{i}, K_{i}$, and $H_{i}$ are, respectively, output, total factor productivity, the input of capital, and the input of labor in sector $i=N, T$, and $\theta$ is the share of capital in production. Investments in the two sectors, $I_{T}$ and $I_{N}$, are produced according to the constant-returns-to-scale technologies:

$$
\begin{aligned}
I_{N} & =\Phi^{N}\left(I_{N, N}, I_{N, T}, I_{N, M}\right) \\
& =\left[a_{I_{N}} \cdot I_{N, N}^{\frac{\sigma-1}{\sigma}}+\left(1-a_{I_{N}}\right) \cdot\left(b_{I_{N}} \cdot I_{N, T}^{\frac{\varepsilon-1}{\varepsilon}}+\left(1-b_{I_{N}}\right) \cdot I_{N, M}^{\frac{\varepsilon-1}{\varepsilon}}\right)^{\frac{\varepsilon(\sigma-1)}{(\varepsilon-1) \sigma}}\right]^{\frac{\sigma}{\sigma-1}}
\end{aligned}
$$

$$
\begin{aligned}
I_{T} & =\Phi^{T}\left(I_{T, N}, I_{T, T}, I_{T, M}\right) \\
& =\left[a_{I_{T}} \cdot I_{T, N}^{\frac{\sigma-1}{\sigma}}+\left(1-a_{I_{T}}\right) \cdot\left(b_{I_{T}} \cdot I_{T, T}^{\frac{\varepsilon-1}{\varepsilon}}+\left(1-b_{I_{T}}\right) \cdot I_{T, M}^{\frac{\varepsilon-1}{\varepsilon}}\right)^{\frac{\varepsilon(\sigma-1)}{\varepsilon-1) \sigma}}\right]^{\frac{\sigma}{\sigma-1}},
\end{aligned}
$$

where $I_{i, j}$ is the intermediate input used to produce investment in sector $i=N, T$, and produced in sector $j=N, T, M$. The parameters $a_{I_{i}}$ and $b_{I_{i}}$ will determine the share of the intermediate inputs. The elasticities between nontradable and tradable inputs, and between domestic and foreign tradable inputs, are restricted to being equal to the elasticities of the consumption aggregator.

The resource constraints are

$$
\begin{aligned}
& Y_{N}=C_{N}+I_{N, N}+I_{T, N} \\
& Y_{T}=C_{T}+I_{N, T}+I_{T, T}+X \\
& M=C_{M}+I_{N, M}+I_{T, M},
\end{aligned}
$$

where $C_{N}, C_{T}$, and $C_{M}$ are the domestic consumption of nontradables, tradables, and imports; $I_{i, T}, I_{i, N}$, and $I_{i, M}$ are the intermediate inputs of nontradables, tradables, and imports used in the production of investment in sector $i=N, T ; X$ is tradable goods exported abroad; and $M$ is total imports. 
Capital in both sectors depreciates at rate $\delta$. Therefore, the stocks of capital evolve according to

$$
K_{i, t+1}=(1-\delta) K_{i, t}+I_{i, t}, \quad i=N, T .
$$

We assume that there is no international mobility of capital. ${ }^{7}$ The equilibrium in the foreign sector is then given by the balance in the trade account, that is,

$$
P_{M, t} \cdot M_{t}=P_{T, t} X_{t}
$$

where $P_{M, t}$ is the price of the imported goods and $P_{T, t}$ is the price of the goods produced in the tradable sector (which is also the price for exports), all measured in terms of the composite consumption good $C_{t}$.

To close the model, we need to specify the demand of exports from the foreign sector. We assume that the real demand of exports is always equal to the real demand of imports, that is, $X=M$. One way to interpret this restriction is by assuming the existence of two symmetric countries both affected by the same shocks and implementing the same policies. Extending the model to the case in which the two countries are affected by different shocks and implement different policies is not difficult. However, for the purpose of this paper, it will be convenient to assume symmetry. Given the assumption that the real demand of exports is equal to the real demand of imports, the equilibrium condition in the trade sector (condition (10)) implies that the price of imports is equal to the price of goods produced in the tradable sector.

Finally, we assume that there is a tariff on imports $\tau_{t}$. The tariff revenue is rebated back to the households through lump-sum transfers. The transfers will be denoted by $T_{t}$ and are equal to $\tau_{t} M_{t} P_{M, t}$.

The optimization problem of the firms in the two sectors is static and consists of the choice of capital and labor to maximize profits, that is,

$$
\max _{K_{i, t}, H_{i, t}}\left\{P_{i, t} \cdot A_{i} K_{i, t}^{\theta} H_{i, t}^{1-\theta}-R_{i, t} K_{i, t}-W_{t} H_{i, t}\right\}, \quad i=N, T,
$$

where $W_{t}$ is the wage rate, $R_{i, t}$ is the rental rate of capital in sector $i=N, T$, and $P_{i, t}$ is the price of goods produced in sector $i=N, T$, all measured in terms of the price of the composite consumption good $C_{t}$.

The solution to the firm's problem is

$$
R_{i, t}=P_{i, t} \cdot \theta A_{i} K_{i, t}^{\theta-1} H_{i, t}^{1-\theta}
$$




$$
W_{t}=P_{i, t} \cdot(1-\theta) A_{i} K_{i, t}^{\theta} H_{i, t}^{-\theta}
$$

Households choose sequences of hours worked, intermediate inputs in the consumption function, and intermediate inputs in the investment functions to maximize (1), subject to the sequence of budget constraints:

$$
\begin{aligned}
W \cdot H & +R_{N} K_{N}+R_{T} K_{T}+T=\left(C_{N}+I_{N, N}+I_{T, N}\right) P_{N} \\
& +\left(C_{T}+I_{T, T}+I_{N, T}\right) P_{T}+\left(C_{M}+I_{T, M}+I_{N, M}\right) P_{M}(1+\tau)
\end{aligned}
$$

and to the technological constraints (2), (4), (5), and (9). Given the sequence of prices and tariffs $\left\{W_{t}, R_{N, t}, R_{T, t}, P_{N, t}, P_{T, t}, \tau_{t}\right\}$, it is straightforward to write down the necessary first-order conditions. After imposing the equilibrium aggregate conditions (6), (7), (8), and (10), the first-order conditions for households and firms, along with the proper transversality conditions, determine the equilibrium of the economy.

\section{Calibration}

We want to interpret the model representative of the Italian nonfarm sector in the interwar period. Therefore, we calibrate the model on an annual basis using data from the nonfarm sector during that period. The utility function is specified as $U\left(C_{t}, 1-H_{t}\right)=\alpha \log \left(C_{t}\right)+(1-\alpha) \log \left(1-H_{t}\right)$, with $\alpha=0.33$. The intertemporal discount rate is set to $\beta=0.96$, which is consistent with an average growth rate of consumption of 1.3 percent and with an average real risk-free rate (rate on government bonds) of 6.2 percent computed for Italy in the period 1920-40 (data from Ercolani 1978).

Two important parameters are the elasticities of substitution between tradables and nontradables, $\sigma$, and between domestic and foreign tradables, $\varepsilon$. Unfortunately, we do not have enough disaggregated data to estimate the two elasticities separately. In particular, it would be problematic to estimate the elasticity between foreign and domestic tradables because in the interwar years, international trade was heavily affected by tariffs and other forms of barriers that are not reflected in the measures we have of international prices. Therefore, we estimate the elasticity between tradables and nontradables directly; but for the elasticity of substitution between domestic and foreign tradables, we use values recently used in the literature. To estimate $\sigma$ we use the first-order conditions for tradable and nontradable consumption. Taking the standard deviation of the $\log$ of the ratio of these first-order conditions, we obtain 


$$
\sigma=\frac{\text { Standard deviation }\left(\log \left(\frac{C_{T}}{C_{N}}\right)\right)}{\text { Standard deviation }\left(\log \left(\frac{P_{T}}{P_{N}}\right)\right)} .
$$

Therefore, the elasticity $\sigma$ can be obtained by taking the ratio of the standard deviations of relative consumption and relative prices of tradables and nontradables. Following this procedure, we estimate $\sigma=0.8$. This value is not very far from the value of 0.5 used by Stockman and Tesar (1995). Following the work of Backus, Kehoe, and Kydland (1994) and other studies in international business cycles, we set $\varepsilon$, the elasticity of substitution between domestic and foreign tradables, equal to 1.5.

The share parameters $a_{C}, b_{C}, a_{I_{N}}, b_{I_{N}}, a_{I_{T}}$, and $b_{I_{T}}$ are set to match the input-output ratios for the nonfarm sector during the interwar years, as reported in Table 3. The construction of these ratios is described in the Data Appendix. These ratios provide eight conditions, but only five are independent. Therefore, to pin down the six share parameters, we need an extra condition. This extra condition could be given by the ratio between the tradable inputs in the production of investment in the tradable and nontradable sectors, that is, $I_{T, T} / I_{N, T}$. Because we do not have data to measure this ratio directly, we simply set this ratio equal to 1 . However, the results are not significantly sensitive to this ratio.

We assume that the production technologies of the two sectors have the same total factor productivity, which we normalize to 1 , that is, $A_{N}=A_{T}=1$. There is no growth in productivity in the model, so the series generated from the model should be interpreted as deviations from a balanced-growth path. The parameter $\theta$ is set to 0.45 , which is the value of the capital income share

Table 3. Average ratios, Italy, 1920-40

\begin{tabular}{llll}
\hline Nontradable ratios & $\frac{C_{N}}{Y_{N}}=.63$ & $\frac{I_{N, N}+I_{T, N}}{Y_{N}}=.37$ & \\
Tradable ratios & $\frac{C_{T}}{Y_{T}}=.55$ & $\frac{I_{N, T}+I_{T, T}}{Y_{T}}=.10$ & $\frac{X}{Y_{T}}=.35$ \\
Import ratios & $\frac{C_{M}}{M}=.60$ & $\frac{I_{N, M}}{M}=.15$ & $\frac{I_{T, M}}{M}=.25$ \\
\hline
\end{tabular}


reported by Vannutelli (1961) for Italy in 1938. The depreciation rate is assigned the value of $\delta=0.1$.

Finally, we calibrate the path for import tariffs. In the model, the import tariff is interpreted as representative of all forms of distortions to the purchase of foreign imports. This includes legal restrictions such as currency control and quota limitations. Therefore, rather than calibrating $\tau$ using direct measurements of import tariffs, we choose values of $\tau$ that generate the observed fall of imports and exports during the recession. Starting from $\tau=0$ in the pre-Depression economy, the desired fall in trade requires a new value of $\tau$ equal to 0.5 . As observed previously, the increase in measured tariffs has been smaller than 50 percent. However, this higher value should be interpreted as accounting for all forms of trade restrictions. Once we take this broader interpretation of the tariff increase, the number is not unreasonable.

\section{A Persistent Shock to Trade}

Before describing the experiment conducted in this section, we recap the key facts that characterized the Great Depression in Italy:

1. Large and persistent decline in imports and exports

2. Large fall in hours and production in the tradable sector but smaller changes in the nontradable sector

3. Large fall in investment

4. Stability of real wages

The facts are quantitatively summarized in Table 4 and will be used as a reference to evaluate the performance of the model.

The fall in international trade is probably the most striking aspect of the period surrounding the Great Depression. Foreign trade was relatively stable until the end of the 1920s, when it started a rapid and persistent decline. This spurs our interest in investigating whether the protectionist policies implemented in the late 1920s and early 1930s may have been an important driving force of the Great Depression in Italy. Studying the political forces behind the adoption of these policies is beyond the scope of this paper. However, there is no doubt that these policies were implemented in Italy and in many other countries, with detrimental effects on international trade. To investigate the importance of these policies, we conduct a simple experiment: starting from the steady state in which $\tau=0$, we consider the unexpected and permanent introduction of an import tariff. We then study the reaction of the economy to the introduction of this tariff. The size of the tariff is such that the fall in imports (and exports) is about 40-45 percent, comparable to the fall in Italian trade in the first half of the 1930s. 


\section{Table 4. Summary statistics of the Great Depression in Italy}

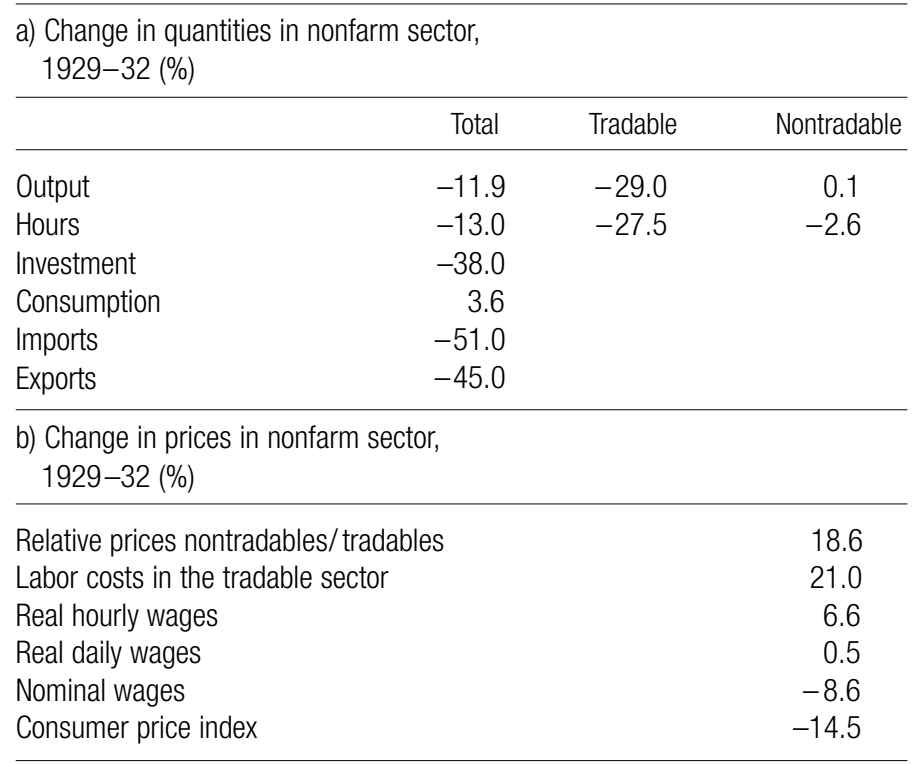

In simulating the model, we consider two cases. In the first case, wages are assumed to be perfectly flexible. In the second case, the real wage is assumed to be fixed during the period of the Depression, after which it becomes flexible. The tariff is introduced in 1930, and the wages are fixed from 1930 through 1938. The wage inflexibility implies that after the tariff increase, the labor market fails to clear. In this case the household first-order condition determining the labor supply is satisfied with the inequality sign, that is,

$$
U_{2}\left(C_{t}, 1-H_{t}\right)<U_{1}\left(C_{t}, 1-H_{t}\right) \cdot \bar{W} .
$$

This simply means that at the fixed wage rate, the marginal disutility from working is smaller than the marginal utility from consuming the wage, and the worker would like to work longer.

The experiment with fixed wages is motivated by the observed constancy of the real wages observed during the contraction period and by the particular wage-setting situation that prevailed in Italy during fascism (see the discussion in the Data Appendix). It also constitutes a way of measuring the contribution of monetary shocks to the Great Depression, similar to the exercise conducted by Cole and Ohanian (2000) for the U.S. economy. One 
can imagine that a perfectly tuned monetary policy would have changed the price level to keep the real wage at the same level that would have prevailed if nominal wages were perfectly flexible. Hence, the difference between the model with sticky wages and the model with flexible wages can be interpreted as the upper bound for the contribution of monetary shocks to the Depression.

Figure 10 (panels $a$ through $f$ ) plots the impulse responses for several aggregate variables. The solid line represents the response of the economy with flexible wages, while the dashed line represents the response of the economy with fixed real wages. The first point to note is that the introduction of the tariff substantially reduces output in both cases (see panel $d$ ). To understand this, we have to keep in mind that a tariff increases the cost of a necessary input of production (foreign tradables) and at the same time, due to the assumption of no international borrowing and lending, lowers the demand for domestic tradables: both of these forces cause a reduction in output. Notice also that the impact of the trade fall on the responses of labor and output is amplified by the real wage rigidity. Investment and consumption also fall, but the fall in consumption is much smaller. Finally, notice that the model predicts a persistent decline in all variables (for example, after nine years, investment is still 18 percent below its long-run trend, and that is consistent with Figure 6).

From a quantitative point of view, panel $d$ shows that the model with flexible wages accounts for a decline in GDP from 1929 to 1932 of around 5.5 percent, that is, about one-half of that observed in the data. Introducing wage rigidities can generate a drop in output of about 8 percent, which is three-fourths of what is observed in the data. Notice also that the extent of the fall in hours is similar to the data (in the case of fixed wages), while the fall in investment in the model is smaller than in the data (in both fixed and flexible wages).

Notice that, due to wage rigidities and changes in relative prices between the tradable and nontradable sectors, wage rigidity affects the labor costs in the two sectors differently. This, in turn, impacts the relative performance of the two production sectors. This performance is illustrated in Figure 11 (panels $a$ through $d$ ). Due to the lower demand for exports, the prices of nontradables increase relative to the prices of tradables initially, after which they fall to a lower level. This pattern is qualitatively consistent with the evidence presented in Figure 7 even though the change in relative prices in the data is larger. Panels $a$ and $b$ show that in both sectors, hours fall. However, the drop is larger in the tradable sector due to the lower demand for exports. A similar pattern is observed for the production in the two sectors: panel $d$ plots the production of nontradables relative to the production of tradables. Again, 
Figure 10. Impulse responses to increased trade restrictions (aggregate variables)

(a) Imports

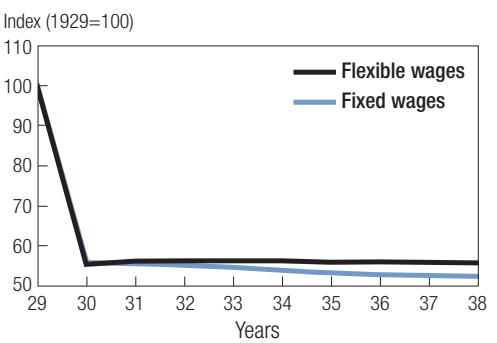

(c) Hours

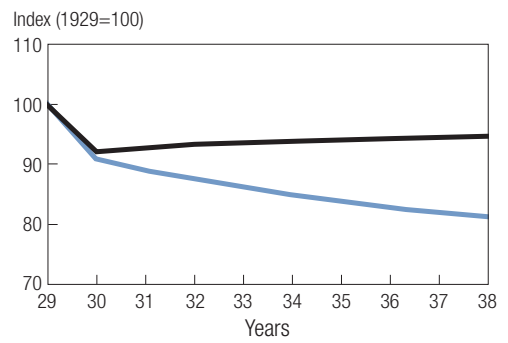

(e) Consumption

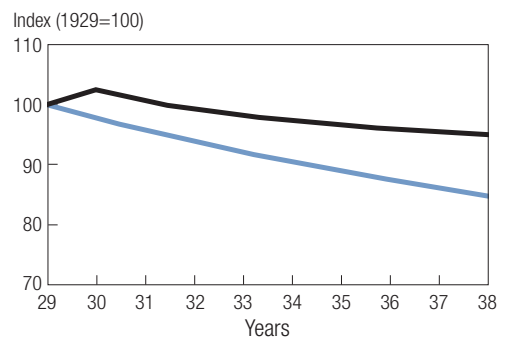

(b) Real wages

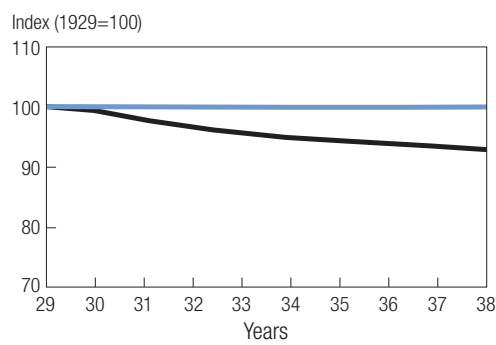

(d) Output

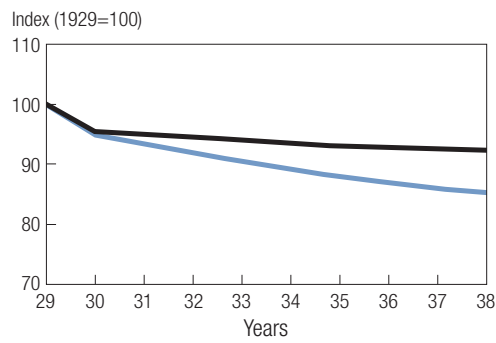

(f) Investment

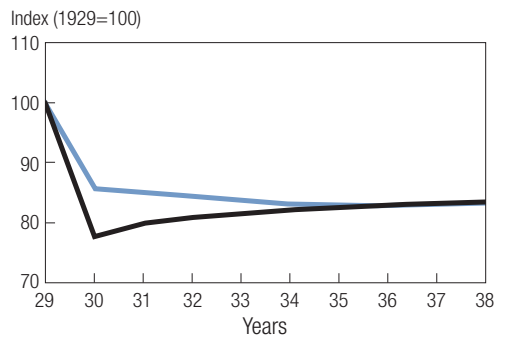

this sectoral pattern is qualitatively consistent with the data even though the differences in the responses of the two sectors are sharper in the data.

These results suggest that the fall in trade had a large impact on production and hours worked. Although the responses of the model do not exactly match all the behaviors of the macro variables and sectoral composition observed in the data, the general pattern is consistent with the main features of the Italian Depression. Therefore, we conclude that the trade restrictions introduced in the late 1920s and early 1930s had a significant impact on the Italian economy 
Figure 11. Impulse responses to increased trade restrictions (sectoral variables)

(a) Tradable sector hours

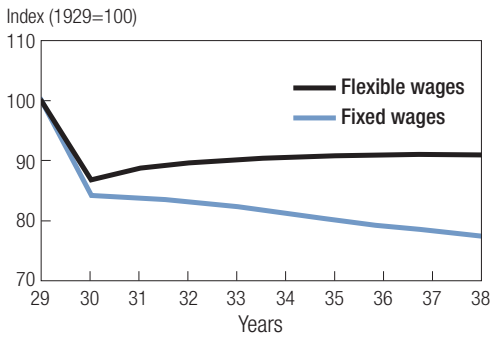

(c) Relative price of nontradables

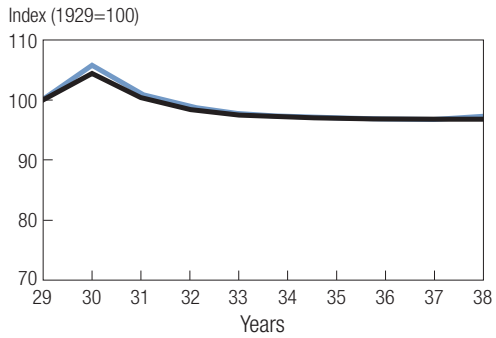

(b) Nontradable sector hours

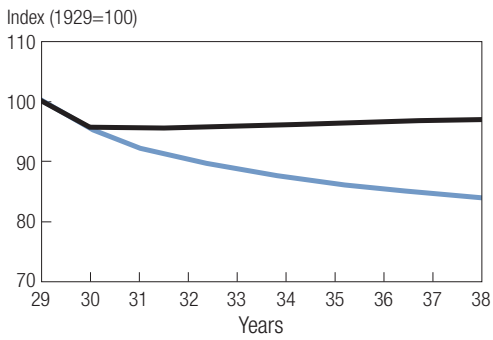

(d) Relative output of nontradables

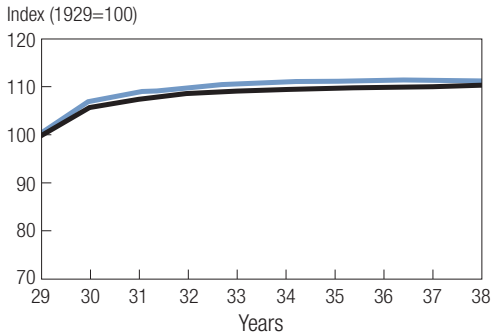

and were an important factor for the Great Depression in Italy. Quantitatively, our model predicts that trade alone can account for one-half of the observed downturn, while real wage rigidities (and thus in a broader sense, monetary shocks) account for one-fourth of the downturn.

To some extent, however, these results depend on the calibration of the elasticities of substitution among consumption and investment inputs. An important parameter is the elasticity of substitution between domestic and foreign tradables. We have experimented with lower and higher values of this elasticity; the main result is that lower values would yield larger output drops while higher values would yield lower output drops. In the model with wage rigidities, an elasticity of 1 , as in the work of Stockman and Tesar (1995), enables the model to generate a drop in output as large as in the data. A value of 2 generates half of the output drop observed in the data. ${ }^{8}$ A more complex model would be one in which the elasticity is allowed to vary over time, being low in the short run and high in the long run. We suspect that this model would probably generate a large response on impact, but a less persistent effect after the introduction of tariffs. 


\section{Conclusions}

The Great Depression was the greatest macroeconomic shock to hit industrialized countries in the twentieth century, and fully understanding it is still a challenge to economists. The simultaneous impact of the Depression on so many countries led us to investigate whether some mechanism of international transmission spread the affliction. More specifically, we investigated the extent to which the fall in international trade was responsible for the economic depression in Italy. Our results suggest that increasing barriers to trade, together with real wage rigidities, can explain a large proportion of the economic downturn experienced by Italy at the beginning of the 1930s. Given this result, it would be interesting to investigate whether the same mechanism could explain the recession experience of other countries during the same period. In particular, we question whether the failure to maintain an international environment of free trade may have been the main cause of the diffusion of the Great Depression worldwide. We leave this and other related questions for future research.

\section{Data Appendix}

The data for Figure 1 are from Maddison 1991.

The data for Figure 2 are from OEEC 1958.

The data for Figure 3 are from Ercolani 1978.

The series for total factor productivity (TFP) in the nonfarm sector in Figure 4 is obtained from the following formula:

$$
\log \left(\mathrm{TFP}_{t}\right)=\log \left(Y_{t}\right)-\alpha \log \left(K_{t}\right)-(1-\alpha) \log \left(H_{t}\right),
$$

where $Y_{t}$ is real output in the nonfarm sector, $K_{t}$ is net capital stock in industry and services reported by Ercolani (1978), and $H_{t}$ is total hours in the nonfarm sector. The parameter $\alpha$ is set to .45 to be consistent with a share of labor income of 55 percent in industry and services, reported by Vannutelli (1961). This series is then detrended by $1.02^{1-\theta}$, which is approximately equal to 1.01 .

Nonfarm imports and exports ratios plotted in Figure 5 are obtained by multiplying the series of nominal imports and exports from Rey 1991 by the share of nonfarm imports and exports reported in Paradisi 1976 and then dividing the series by nominal nonfarm output (obtained from Rey 1991, subtracting agricultural output from total output). ${ }^{9}$

The series for per capita output, consumption, investment, and hours in the nonfarm sector shown in Figure 6 are obtained as follows: Real output in the nonfarm sector is computed by aggregating all nonfarm sectors from the sectoral value-added data; real consumption is obtained by subtracting food consumption from total con- 
sumption; and investment is obtained by subtracting investment in agriculture from total investment. All original series are from Ercolani 1978. Hours are obtained by summing total hours in the industrial sector (from Zamagni 1994) plus total hours in the service sector (from Rossi, Sorgato, and Toniolo 1993). All series are divided by midyear population estimates (from Rey 1991).

The relative prices reported in Figure 7 are the ratio of nontradable prices to tradable prices (with and without agricultural prices). The price index for tradables is constructed taking the ratio between current and constant prices gross product of manufacturing and mining with and without agriculture. The price index for nontradables is computed in the same way, aggregating the following sectors: construction; electricity, gas, and water; transportation; commerce, credit, and insurance; various services; and building services. The source for the original data is Ercolani 1978.

The data in Figure 8 are constructed as follows: For nominal wages in the tradable sector, we use industrial hourly wages reported by Zamagni (1994). For nominal wages in the nontradable sector, we use the hourly nominal wages in the service sector reported by Rossi, Sorgato, and Toniolo (1993). Real wages in the two sectors (tradables and nontradables) are obtained by dividing the nominal wage series by the price index for the two sectors. For total hours worked in the tradable sector, we use total hours in industry reported by Zamagni (1994). For total hours in the nontradable sector, we use hours in the service sector reported by Rossi, Sorgato, and Toniolo (1993). The data in Figure 9 are constructed as follows: Real hourly wages are nominal hourly wages in industry reported by Zamagni (1994), deflated by CPI (reported also by Zamagni 1994). Daily real wages is real hourly wages times the average hours worked per day, as in Zamagni 1994.

The ratios in Table 3 are constructed as follows: For the nontradable ratios, we construct a series for nontradable consumption $\left(C_{N}\right)$, adding consumption of housing, transportation, health, education, and entertainment, plus 50 percent of other goods and services. (Consumption series are from Rossi, Sorgato, and Toniolo 1993.) We then construct a series for nontradable output $\left(Y_{N}\right)$, adding output of construction; electricity, gas, and water; transportation; commerce, credit, and insurance; various services; and building services (from Ercolani 1978).

For the tradable ratios, we construct a series for nonfarm tradable consumption $\left(C_{T}\right)$, adding consumption of clothing, furniture, and fuels, plus 50 percent other goods and services (consumption series are from Rossi, Sorgato, and Toniolo 1993). We construct a series for nonfarm tradable output $\left(Y_{T}\right)$, adding output from manufacturing and mining (from Ercolani 1978) and a series for nonfarm export $(X)$. (See the description for the data in Figure 5.) Finally, we use data reported by Paradisi (1976, Table 2A) to disaggregate nonfarm imports into three categories. We identify imports of textile products, wood, and rubber as imports of consumption goods $\left(C_{M}\right)$, we identify imports of construction materials as imports of investment goods for the nontradable sector $\left(I_{N, M}\right)$, and we identify the remaining nonfarm imports as imports of investment goods for the tradable sector $\left(I_{T, M}\right)$. The ratios reported in Table 3 are derived from taking the average of the series just described in the period $1920-40$. 


\section{Notes}

Reprinted from Review of Economic Dynamics, Vol. 5, Fabrizio Perri and Vincenzo Quadrini, "The Great Depression in Italy: Trade Restrictions and Real Wage Rigidities," pages 128-151, copyright 2002, with permission from Elsevier.

This paper was originally prepared for the "Great Depressions of the Twentieth Century" conference held on October 20-21, 2000, at the Federal Reserve Bank of Minneapolis. We thank our discussant Ellen McGrattan, the conference organizers, the participants, and a referee for helpful comments. All remaining errors are our own.

1. A recent contribution is the work by Mattesini and Quintieri (1997); Piva and Toniolo (1987) have a very interesting work on the Italian labor markets during the Great Depression.

2. The deviations from trend are obtained assuming a common long-run growth trend of 2 percent per year (as in most other papers in this volume) and that all the economies were on trend in 1929.

3. To get a feeling for the magnitude of the Depression, it might be useful to compare the 1929 contraction in the United States to the 1973 contraction, the sharpest in the U.S. postwar period. In the decline that started in 1973, GDP per capita contracted 2.6 percent and took three years to go back to the 1973 level, while industrial production per capita fell by 11.7 percent and took four years to return to the 1973 level.

4. The turning point in Italian trade policy was the nomination in 1925 of finance minister Giuseppe Volpi, who abandoned the previous liberal trade policy to adopt a series of protectionist measures in order to restore the gold convertibility of the lira (the quota ninety policy). After convertibility was restored (at the end of 1927), a series of international trade sanctions were imposed on Italy because of the Italian invasion of Ethiopia. In response to the sanctions, Italy adopted an even more strict protectionist policy, and by the early 1930s, after the sovra-dazio (extra-tariff) of 1931, autarky was the explicit goal of the fascist trade policy.

5. Ciocca (1976) noticed the importance of the collapse in world trade for the Italian economy, suggesting that "the repercussions of this phenomenon [the collapse of world trade] for the Italian economy are yet to be quantified but they cannot be unimportant for a country in transformation in which the lack and deficiency of primary resources is a fundamental characteristic."

6. Salvemini $(1936,363)$ reports the following quote by Einzig: "In no country was it so easy as in Italy to obtain the consent of employees to a reduction of wages."

7. The assumption is largely motivated from the empirical evidence showing how imports and exports moved very closely together, and from the more direct evidence that international capital flows came to an almost complete stop in the late 1920s (see Feinstein, Temin, and Toniolo 1997).

8. Complete results of the sensitivity experiments are available from the authors upon request.

9. The share for nonfarm imports and exports is reported for the years 1922, 1926, 1929, 1932, 1936, and 1938 only. For the remaining years we have used linear interpolation. 


\section{References}

Backus, David K.; Patrick J. Kehoe; and Finn E. Kydland. 1994. Dynamics of the trade balance and the terms of trade: The J-curve? American Economic Review 84 (March): 84-103.

Bernanke, Ben S., and Kevin Carey. 1996. Nominal wage stickiness and aggregate supply in the Great Depression. Quarterly Journal of Economics 111 (August): 853-83.

Ciocca, Pierluigi. 1976. L'economia italiana nel contesto internazionale. In L'economia Italiana nel periodo fascista, ed. Pierluigi Ciocca and Gianni Toniolo, 19-50. Bologna: Il Mulino.

Cole, Harold L., and Lee E. Ohanian. 1999. The Great Depression in the United States from a neoclassical perspective. Federal Reserve Bank of Minneapolis Quarterly Review 23 (Winter): 2-24.

2000. Re-examining the contributions of money and banking shocks to the U.S. Great Depression. Research Department Staff Report 270. Federal Reserve Bank of Minneapolis.

2001. New Deal policies and the persistence of the Great Depression: A general equilibrium analysis. Working Paper 597. Federal Reserve Bank of Minneapolis.

Crucini, Mario J., and James Kahn. 1996. Tariffs and aggregate economic activity: Lessons from the Great Depression. Journal of Monetary Economics 38 (December): 427-67.

Ercolani, Paolo. 1978. Documentazione statistica di base. In Lo sviluppo economico in Italia, ed. Giorgio Fuà, Vol. 3, 388-472. Milano: Franco Angeli.

Feinstein, Charles; Peter Temin; and Gianni Toniolo. 1997. The European economy between the wars. Oxford: Oxford University Press.

Guarneri, Felice. 1988. Battaglie economiche fra le due guerre. Bologna: Il Mulino.

Maddison, Angus. 1962. Growth and fluctuations in the world economy 1870-1960. Banca Nazionale del Lavoro Quarterly Review (June): 3-71.

. 1991. Dynamic forces in capitalist development. Oxford: Oxford University Press.

Mattesini, Fabrizio, and Beniamino Quintieri. 1997. Italy and the Great Depression: An analysis of Italian economy, 1929-1936. Explorations in Economic History 34 (July): 265-94.

Organization for European Economic Cooperation (OEEC). 1958. Industrial statistics, 1900-1957. Paris: OEEC.

Paradisi, Mariangela. 1976. Il commercio estero e la struttura industriale. In L'economia Italiana nel periodo fascista, ed. Pierluigi Ciocca and Gianni Toniolo, 271-328. Bologna: Il Mulino.

Piva, Francesco, and Gianni Toniolo. 1987. Sulla disoccupazione in Italia negli anni '30. Rivista di Storia Economica, 2nd series, 4:345-83.

Rey, Guido. 1991. I conti economici dell'Italia. Bari: Laterza. 
Rossi, Nicola; Andrea Sorgato; and Gianni Toniolo. 1993. I conti economici Italiani: Una ricostruzione statistica, 1890-1990. Rivista di Storia Economica 10:1-47.

Salvemini, Gaetano. 1936. Under the axe of fascism. New York: Viking Press.

Stockman, Alan C., and Linda L. Tesar. 1995. Tastes and technology in a two-country model of the business cycle: Explaining international comovements. American Economic Review 85 (March): 168-85.

Vannutelli, Cesare. 1961. Occupazione e salari in Italia dal 1861 al 1961. Rassegna di Statistiche del Lavoro.

Zamagni, Vera N. 1976. La dinamica dei salari nel settore industriale. In L'economia Italiana nel periodo fascista, ed. Pierluigi Ciocca and Gianni Toniolo, 19-50. Bologna: Il Mulino.

1994. Una ricostruzione dell'andamento mensile dei salari industriali e dell' occupazione 1919-39. In Ricerche per la storia della Banca d'Italia, Vol. 5, 348-78. Bari: Laterza. 